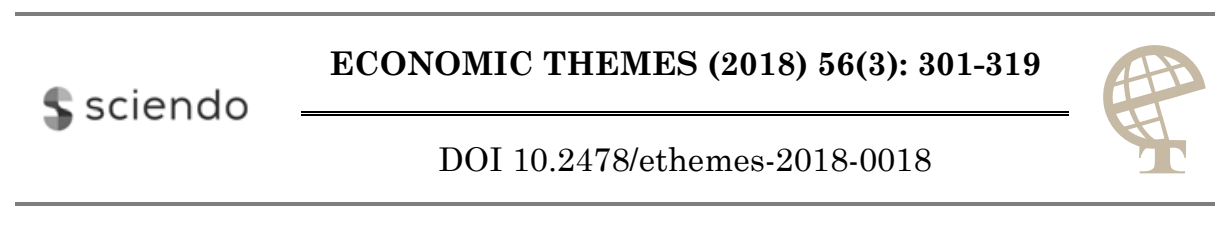

\title{
TEAM LEARNING PROCESSES AND ACTIVITIES IN ORGANIZATION: A CASE STUDY
}

\author{
Snežana Lazarević \\ College of Sports and Health, Belgrade, Serbia \\ $\triangle$ snezanalazarevic@vss.edu.rs \\ Jelena Lukić \\ Modern Business School, Belgrade, Serbia \\ $\triangle$ jelena.lukic@mbs.edu.rs
}

UDC

005.64

Original

scientific

paper

Received:

29.01.2018

Accepted:

28.05.2018

\begin{abstract}
Organizations in today's environment are relied on teams and their learning as key determinants for survival and success. The aim of this paper is to identify the key team learning processes and activities in organizations and to examine how the eventual appearance and growth of the problems in team impact on those processes and activities. Research was conducted in nine teams with 79 members in one public service organization located in Belgrade, Serbia, using interview and questionnaire techniques. Descriptive analysis, linear regression and Pearson correlation coefficient were used for processing and interpreting collected data. The results show that undefined roles of team members, a lack of trust among them, inadequate rewards, inadequate leadership and team management, will cause a moderate decrease in team learning processes and activities. The value of this research is that growing reliance on teamwork in organizations put pressure on leaders and managers to understand the factors that enable and stimulate team learning processes and activities, but also to identify and overcome all problems that may arise in teams and slow down the learning in teams as one of the most important processes.
\end{abstract}

Keywords: Teams, Team learning, Problems in team, Team learning processes and activities

JEL classification: 033, L21 


\section{Introduction}

Since the beginning of the $21^{\text {st }}$ century, globalization and continuous technological advancements caused the changes in organizations and their structures (Petković \& Lukić, 2014). These changes have lead to very different forms of organizing activities and processes in organizations and consequently changes in organizing employees (Graetz \& Smith, 2005). Organizational structure which has proved to be effective in practice is characterised with more flattening structure, decentralized decision-making, greater collaboration and knowledge transfer among employees (Senge, 1990; Garvin, 1993; Miles et al. 2010). Many managers have found all these characteristics in teams and consequently developed team-based organizational structures (Eddy et al. 2013).

Through history, teams have had a higher level of knowledge, various skills, expertise and experience comparing to individuals (Tannenbaum et al. 2012). These team characteristics are stimulative and give team members the opportunity to learn from one another while working together (Woerkom \& Croon, 2009). Managers realized how important is for organizations to take advantage of that opportunity, because knowledge has been named as a factor of competitive advantage and a crucial resource that gives the organization the ability to use its resources effectively (Garvin et al. 2008). That is the reason why learning in teams and all the processes and activities that support it are very important for organizational survival and success. The main motivation of the paper was to identify and analyse the impact of problems which may appear in team on team learning processes and activities. A case study method was conducted, using the interview and questionnaire techniques for data collection, in one public service organization based in Belgrade, Serbia, whose basic functional structure is upgraded with many different teams. Descriptive analysis, linear regression and the Pearson correlation coefficient were used for processing and interpreting collected data.

The first part of the paper points out the importance of learning in teams, key processes and activities that support learning in teams, problems which may arise in teams and their impact on those processes and activities. The second part of the paper is focused on the concept of research - the aim, importance, object of research and description of the research sample, while the third and fourth parts of the paper are focused on results and discussion of research findings.

\section{The Importance of Team Learning: Literature Review}

Nowadays, as basic organizational structures are upgraded with many different teams and became so-called team-based structures (Mohrman et al. 1995), the ability of organizations to learn is reliant on the ability of their teams to learn (Edmondson et al. 2007; Ashauer \& Macan, 2013). Working teams in organizations operate in dynamic and uncertain environment and collaborate with each other not only in internal 
organization, but also externally with many different actors (Harvy et al. 2014). For that reason, they must be able to constantly learn and adapt themselves in order to properly operate and achieve desired goals (Lehmann-Willebrock, 2017). Peter Senge has identified five disciplines of learning organizations, among which one discipline is especially focused on team learning. According to that discipline, team learning happens every time when a team in organization is formed, no matter if it is formed for short-term or long-term purposes and goals and represents a process of "aligning and developing the capacities of a team to create the results its members truly desire" (Senge, 1990, p. 236). It also represents a continuous process of acquiring, sharing and combining knowledge among team members, experimentation, reflection, action, discussion of different opinions, possible errors, and testing assumptions (Edmondson, 1999; Edmondson et al. 2007) which consequently improves team outcomes (Kozlowski \& Ilgen 2006; Wiedow et al. 2013). It is important to emphasize that team learning is not just about individual employees who are gathered to learn together, but it represents interplay between and within all levels in organization.

Team learning has been positioned as an important process through which team members develop, renew and sustain their performance results, and quickly adapt to changes in surroundings (Bell, Kozlowski \& Blawath, 2012). Comparing to individual learning, team learning involves interaction among team members regarding gathering, sharing and processing of information and knowledge, but also agreement among team members about acceptable behaviour for knowledge sharing and further acting (Kayes \& Burnett, 2006). Team members which are engaged in learning processes and activities ask questions, explore different views and perspectives of the problem, examine all assumptions, possible results and consequently change their learning behaviour through time (Lehmann-Willenbrock, 2017). Team learning represents movement from individual learning and serves as the basis for achieving organizational learning (Argyris \& Schon, 1978; Kayes \& Kayes, 2011). It is a compilation of team processes that should generate improvement, firstly at the level of a team, and secondly at the level of individual employees or the organization (Decuyper et al., 2010). But, team learning requires that members adjust their behavior in relation to shared goals, take risks and remain open to exchange of information, knowledge and perspectives with others (Bunderson \& Reagans, 2011). In that way, while team members interact with one another, knowledge and skill gathered by one team member are transferred to others. Consequently, that can raise the efficiency and effectiveness of the collective learning process in teams and furthermore in the overall organization (Ellis et al. 2003). It is believed that teams represent core agents of learning and generators of innovation because they share information and create new ideas and opportunities through active discussion and dialogue (Babnika, Trunk Širca \& Dermol, 2014).

Since the beginning of the $21^{\text {st }}$ century, team learning has become the subject of considerable attention (Van der Haar et al. 2013; Guchait \& Hamilton, 2013; Hedlund \& Österberg, 2013), but even today, team learning is not completely 
understood and requires further examination. The important fact which is often neglected is that team learning requires an environment in which team members are encouraged to experiment, freely state new ideas, learn from each other, develop their full potential and creativity (Berber \& Slavić, 2016). High performing teams started their learning processes and activities by fostering and generating new ideas from diverse members (Goldsmith, Morgan \& Ogg, 2004). Furthermore, as many nowadays teams are confronted with uncertain and dynamic environment, they must be constantly engaged in learning activities and processes in order to understand their customers and achieve improvements (Woerkom \& Croon, 2009). For that reason, organizations have an important role in supporting and nurturing team effectiveness (Bell \& Kozlowski, 2012), and in stimulating learning in teams through learning processes, supporting practices and leadership (Garvin et al. 2008). Team members need to be encouraged to learn how to work together, learn together, share information, make decisions, solve problems and adapt fast to the changes in the environment.

Many authors, who have dealt with teams and teamwork, examined the factors necessary for efficient and effective teams (Lazarević, 2014). The common factors for all authors are clear goals, dedication of members to goal achievement, rewards, precise roles of team members, an appropriate level of knowledge and skills, constant learning in teams, mutual trust, the existence of team leaders who will motivate and direct team members to constantly learn (Edmondson, 1999; Edmondson et al. 2003; McShane \& Von Glinow, 2009; Tannenbaum et al. 2012). A lack of these factors may result in problems that lead to inefficiency and ineffectiveness of teams, because of their negative effect on activities and processes, especially on one of the most important processes in teams - team learning. For that reason, it is very important to extend general understanding about problems which may appear in teams and examine their impact on team learning processes and activities.

\section{The Concept of the Research}

The aim of the research. Team learning processes have been positioned among the main factors which are necessary for team's and organizational performance. Many academics and scholars focused their research on learning in teams and all the processes and activities that support it (Bell \& Kozlowski, 2012). By reviewing the literature, it is identified the gap in existing researches regarding the problems that may appear in teams and consequently their impact on team learning processes and activities. For that reason, the main motivation and aim of this research is to examine which problems, that may appear in teams, impact on team learning processes and activities and how that impact is manifested.

The importance of the research. The importance of the research lies in the fact that a growing reliance on teamwork in organizations puts pressure on team leaders 
and managers to understand the factors that enable and stimulate learning processes and activities in teams (Edmondson, 1999), but also to identify and overcome some problems in teams that may arise and slow down the learning processes.

The object of the research. Research was conducted in one public service organization which is founded in 1892 and located in Belgrade, Serbia (hereinafter: Organization X). Organization X has more than 2000 of employees and very complex organizational structure consisting of seven departments and six organizational units. The main characteristics of its structure are high specialization, a high level of formalization and standardization of work processes, knowledge and skills, a high level of centralization and a small span of control. Regarding departmentalization, Organization $\mathrm{X}$ has a functional grouping of its units but its basic organizational structure is upgraded with many different teams which give this organization the necessary flexibility and adaptability to environmental factors. What is similar for all organizations from the public sector, as in Organization X, is that traditional reward systems are applied for rewarding employees.

The first phase of research: interview with the top management. The first phase of the research consisted of interviewing the top management of the Organization X. During the first interview were identified nine working teams which ideally represent the main processes and functioning of Organization X. The main characteristics of these teams are their permanent structure and clearly established boundaries among teams, although team members may interact with other teams. These teams are: (1) the team for investment activities and warehousing (five team members); (2) the team for supply, distribution, sale and control (seven team members); (3) the team for planning, management and traffic control (six team members); (4) the team for monitoring the exploitation of traffic (fifteen team members); (5) the team for maintaining vehicles (fourteen team members); (6) the team for maintaining of rolling stock and infrastructure (sixteen team members); (7) the team for technical support (six team members); (8) the team for development and system engineering (five team members); and (9) the team for legal and employee jobs (five team members). Regarding the number of team members, it can be concluded that teams for monitoring the exploitation of traffic, maintaining of vehicles and maintaining of rolling stock and infrastructure have a larger number of team members, which is not surprising having in mind the core business of Organization $\mathrm{X}$ and its working processes. Other teams have an almost unified number of members, which is according to literature, an optimal number for effective team functioning (McShane \& Von Glinov, 2009).

After identifying key working teams, during second interview with top management of Organization $X$ were also identified the key problems which may appear in teams, and the key team learning processes and activities which are used as a basis for formulating the questionnaire. 
The second phase of the research: questionnaire and research variables. The second phase of the research was conducted by using the questionnaire technique for data collection. All statements in questionnaire were categorized in three variables which were marked as variable 1: Problems in Team (V1), variable 2: Learning Processes in Teams (V2), and variable 3: Activities in Team Learning Processes (V3).

Problems in Team (V1) is an independent variable that shows the main problems which can appear in the learning processes in teams. This variable encompasses the following statements: inadequate knowledge and inexperience of team members (S1), undefined roles of team members (S2), a lack of trust among team members (S3), inadequate rewards of team members (S4), and inadequate leadership and team management (S5).

Learning Processes in Teams (V2) is a dependent variable which encompasses the following statements: systematically collected and shared information (S1'), open expression of new information (S2'), promptly shared and implemented new knowledge (S3'), new ideas and attitudes are freely stated (S4'), rapid sharing of opinions and attitudes (S5'), complex problems are deeply examined (S6'), need for implementation of new practices and activities (S7'), assisting and helping other teams in an organization (S8'), rapidly develop new skills (S9'), teamwork is the best way for solving many problems (S10'), team learning is rewarded and appreciated (S11'), the team is a place where new knowledge, skills and expertise is acquired in the most efficient way (S12'), all team members are actively involved in problem-solving (S13'), teamwork is stimulative for implementing changes and better work practices (S14'), team members are happy to allocate some additional time for learning (S15'), and problems among team members are stimulative for teamwork and team learning (S16').

Activities in Team Learning Processes (V3) is a dependent variable which encompasses the following statements: a large number of different ideas and opinions leads to the right solutions (S1'), weakness and errors are freely admitted among team members (S2'), constructive dialog and discussion are used for better solutions (S3"), team members can openly discuss their opinions and new ideas (S4'), team meetings are interesting (S5'), differences in ideas and opinions are welcomed (S6'), learning new different methods of work is welcomed (S7'), and freely stating opinions even if that can cause conflicts (S8').

The respondents were asked to range all the statements from abovementioned variables according to their impact on team learning. Therefore, a five-point Likert scale was used in all questions with anchors ranging from strongly disagree (1) to strongly agree (5).

Statistical techniques used in processing collected data. All collected data from the questionnaire were analyzed using Statistical Package for Social Sciences, known as SPSS, version 20 (IBM, Armonk, NY). The statistical significance was set at $\mathrm{p}<$ 
0.05 and $p<0.01$. For all collected data were calculated descriptive parameters: mean (M), a standard deviation (SD) and a standard error of measurement (SE). The Cronbach's Alpha Coefficient has been calculated for all the main variables - Problems in Team (V1), Learning Processes in Teams (V2), and Activities in Team Learning Processes (V3). Linear regression analysis and the Pearson correlation coefficient were also used for statistical analyses of collected data.

Sample description. Seventy-nine team members (57 males and 22 females) from nine teams participated in the study. Based on the Cohen guidelines, G*Power statistical software was used in order to conduct a sample size estimate (Cohen, 1988). With the parameters of alpha level of 0.05 , power of 0.8 and medium effect size of 0.3 according to recommendations of Cunningham and McCrum-Gardner (Cunningham \& McCrum-Gardner, 2007), the sample size of around 80 participants appeared to be necessary to detect which problems in the teams affect learning processes and activities. Therefore, 79 participants from Organization $\mathrm{X}$ in this research was an adequate sample. Results showed that, regarding the age structure of the surveyed team members $42 \%$ of employees were between 31 and 40 years old, $28 \%$ of employees were between 41 and 50 years old, $23 \%$ of employees were old more than 51, and $7 \%$ of employees were between 21 and 30 years old. The structure of team members regarding their working experience is the following: twenty team members have experience between 5 and 10 years, twenty-six team members have experience between 11 and 20 years, twenty-five team members have experience between 21 and 30 years, and eight team members have experience above 31 years.

\section{Research Results}

Regarding results of Cronbach's Alpha Coefficient presented in Table 1, all results are acceptable and show the existence of reliability among statements in all the main variables. Problems in Team (V1) and Learning Processes in Teams (V2) have a value of Cronbach's Alpha Coefficient greater than 0.8 which represents great reliability (Field, 2009), while the variable Activities in Team Learning Processes (V3) has the value of Cronbach's Alpha Coefficient 0.783 (almost 0.8) which represents an acceptable reliability (George \& Mallery, 2003).

Table 1. The values of Cronbach's Alpha Coefficient

\begin{tabular}{|l|c|}
\hline Variables & Cronbach's Alpha Coefficient \\
\hline Problems in Team (V1) & 0.823 \\
\hline Learning Processes in Teams (V2) & 0.920 \\
\hline Activities in Team Learning Processes (V3) & 0.783 \\
\hline
\end{tabular}


Based on theoretical assumptions and empirical research, the main problems which can be a barrier for effective team learning were identified and defined in the form of statements. These statements, having in mind the fact that they represent the common problems of teams, can be defined as one homogenous variable - Problems in Team (V1), but furthermore, each statement has its own scalar value and can be treated as an independent variable. Therefore, each assumed problem can be analyzed by using the methods of parametric statistics. The same has been done for variables Learning Processes in Teams (V2) and Activities in Team Learning Processes (V3). Central and dispersion parameters (mean value, standard deviation and standard error) are calculated for all statements in all variables and presented in Table 2.

The results of descriptive analysis show that the mean values of dependent variables Learning Processes in Teams (V2) and Activities in Team Learning Processes (V3) are above 3.5, and for the independent variable Problems in Team (V1) is somewhat lower (3.109), which indicates that the responses of team members are grouped on a positive side of the value scale - the largest number of frequencies are grouped around the answer "mostly agree". Based on the scalar average, it is identified that the majority of respondents are on the level of the whole sample, as the most significant Problems in Team are stated "Inadequate rewards" (3.468) and "Undefined roles of team members" (3.241). "Lack of trust among team members" (2.853) and "Inadequate leadership and team management" (2.937) are rated as the smallest problems.

The following phase of the research consisted of examining all the assumptions that are needed in order to calculate correlation coefficient. As all assumptions were satisfied (absence of outliers, normality of variables, linearity and homoscedasticity), correlations among variables are calculated using parametric measure - Pearson correlation coefficient.

Figure 1 shows the correlations among examined variables in terms of the strength and direction of the relationships. Problems in Team (V1) and Learning Processes in Teams (V2) are in a negative relationship, which means that increases in Problems in Team cause a slight decrease in Learning Processes in Teams. The relationship is negative and moderate $(\mathrm{r}=0.418)$. Also, the variables Problems in Team (V1) and Activities in Team Learning Processes (V3) are in a negative moderate relationship $(\mathrm{r}=0.380)$. 
Table 2. Descriptive analyses for all statements in the variables Problems in Team (V1), Learning Processes in Teams (V2), and Activities in Team Learning Processes (V3)

\begin{tabular}{|c|c|c|c|}
\hline Variables & $\overline{\mathbf{M}}$ & SD & SE \\
\hline Problems in Team (V1) & 3.109 & .980 & .111 \\
\hline Inadequate knowledge and inexperience of team members (S1) & 3.063 & 1.284 & .145 \\
\hline Undefined roles of team members (S2) & 3.241 & 1.201 & .135 \\
\hline Lack of trust among team members (S3) & 2.835 & 1.334 & .150 \\
\hline Inadequate rewards of team members (S4) & 3.468 & 1.207 & .136 \\
\hline Inadequate leadership and team management (S5) & 2.937 & 1.399 & .157 \\
\hline Learning Processes in Teams (V2) & 3.790 & .075 & .670 \\
\hline Systematically collected and shared information (S1') & 3.773 & .999 & .112 \\
\hline Open expression of new information (S2') & 4.142 & .957 & .108 \\
\hline Promptly shared and implemented new knowledge (S3') & 3.751 & 1.019 & .115 \\
\hline New ideas and attitudes are freely stated (S4') & 3.756 & 1.031 & .116 \\
\hline Rapid sharing of opinions and attitudes (S5') & 3.873 & .925 & .104 \\
\hline Complex problems are deeply examined (S6') & 4.082 & .917 & .103 \\
\hline Need for implementation of new practices and activities (S7') & 3.991 & .967 & .109 \\
\hline Assisting and helping other teams in an organization (S8') & 3.856 & .988 & .111 \\
\hline Rapidly develop new skills (S9’) & 3.738 & .943 & .106 \\
\hline Teamwork is the best way for solving many problems (S10') & 4.273 & .843 & .095 \\
\hline Team learning is rewarded and appreciated (S11') & 3.371 & 1.189 & .134 \\
\hline $\begin{array}{l}\text { The team is a place where new knowledge, skills and } \\
\text { expertise is acquired in the most efficient way (S12') }\end{array}$ & 3.618 & .939 & .106 \\
\hline $\begin{array}{l}\text { All team members are actively involved in problems-solving } \\
\text { (S13') }\end{array}$ & 3.826 & .997 & .112 \\
\hline $\begin{array}{l}\text { Teamwork is stimulative for implementing changes and better } \\
\text { work practices (S14') }\end{array}$ & 3.925 & .844 & .095 \\
\hline $\begin{array}{l}\text { Team members are happy to allocate some additional time for } \\
\text { learning (S15') }\end{array}$ & 3.392 & 1.055 & .119 \\
\hline $\begin{array}{l}\text { Problems among team members are stimulative for teamwork } \\
\text { and team learning (S16') }\end{array}$ & 3.274 & 1.206 & .136 \\
\hline Activities in Team Learning Processes (V3) & 3.691 & .071 & .630 \\
\hline $\begin{array}{l}\text { Large number of different ideas and opinions lead to right } \\
\text { solutions (S1') }\end{array}$ & 4.337 & 693 & .078 \\
\hline $\begin{array}{l}\text { Weakness and errors are freely admitted among team } \\
\text { members (S2"') }\end{array}$ & 3.158 & 1.110 & .125 \\
\hline $\begin{array}{l}\text { Constructive dialog and discussion are used for better } \\
\text { solutions (S3,') }\end{array}$ & 3.294 & 1.167 & .131 \\
\hline $\begin{array}{l}\text { Team members can openly discuss their opinions and new } \\
\text { ideas (S4') }\end{array}$ & 3.872 & 1.005 & .113 \\
\hline Team meetings are interesting (S5',) & 3.815 & .833 & .094 \\
\hline Differences in ideas and opinions are welcomed (S6'") & 3.862 & .997 & .112 \\
\hline Learning new different methods of work is welcomed (S7'') & 3.851 & .878 & .099 \\
\hline Freely stating opinions even if that can cause conflicts (S8') & 3.342 & 1.239 & .139 \\
\hline
\end{tabular}


Furthermore, the coefficient of determination $\left(\mathrm{R}^{2}\right)$ shows that $17.46 \%$ of the total variation in Learning Processes in Teams (V2) can be explained by the linear relationship between Problems in Team (V1) and Learning Processes in Teams (V2), while the other $82.54 \%$ of the total variance remains unexplained. Regarding the total variation in Activities in Team Learning Processes (V3), $14.45 \%$ of variation can be explained by the linear relationship between Problems in Team (V1) and Activities in Team Learning Processes (V3), while the other $85.55 \%$ of the total variation remains unexplained.

Figure 1. Correlations among Problems in Team (V1) with regards to Learning

Processes in Teams (V2) and Activities in Team Learning Processes (V3) in terms of the strength and direction of the relationships
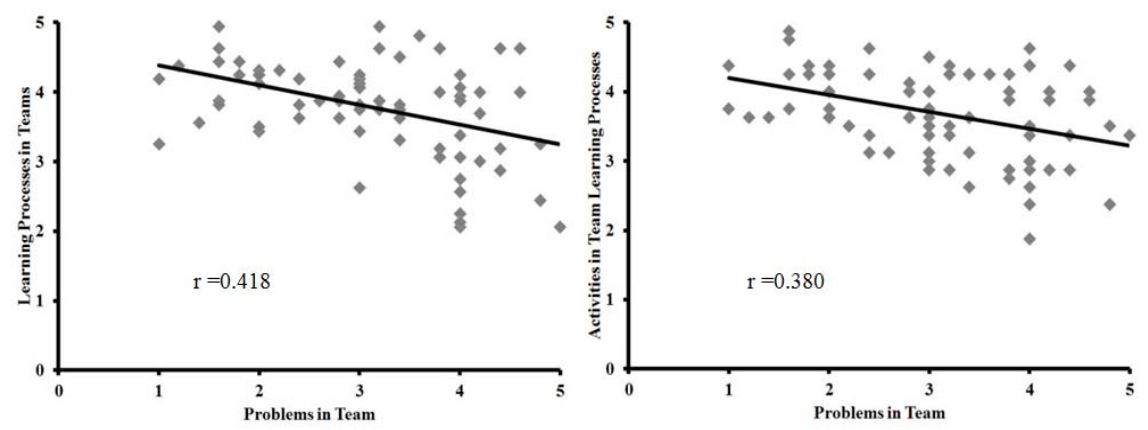

Table 3 represents the results of the Pearson correlation coefficient which shows negative correlations with moderate intensity among independent variable Problems in Team (V1) with regards to dependent variables Learning Processes in Teams (V2) and Activities in Team Learning Processes (V3). The statement regarding the problem of inadequate knowledge and inexperience of team members (S1) from variable Problems in Team (V1) is not showing a statistically significant difference regarding Learning Processes in Teams (V2) and Activities in Team Learning Processes (V3).

Table 3. Correlations among statements (S1-S5) in Problems in Team (V1) with regards to Learning Processes in Teams (V2) and Activities in Team Learning Processes (V3).

\begin{tabular}{||c|c|c||}
\hline $\begin{array}{l}\text { Statements regarding } \\
\text { Problems in Team (V1) }\end{array}$ & $\begin{array}{c}\text { Learning Processes in } \\
\text { Teams (V2) }\end{array}$ & $\begin{array}{c}\text { Activities in Team Learning } \\
\text { Processes (V3) }\end{array}$ \\
\hline S1 & -.144 & -.159 \\
\hline S2 & $-.413^{* *}$ & $-.322^{* *}$ \\
\hline S3 & $-.419^{* *}$ & $-.363^{* *}$ \\
\hline S4 & $-.301^{* *}$ & $-.282^{*}$ \\
\hline S5 & $-.324^{* *}$ & $-.326^{* *}$ \\
\hline
\end{tabular}

$* * \mathrm{p}<0.01,{ }^{*} \mathrm{p}<0.05$ 
Regarding the Pearson correlation coefficient presented in Table 4, statements from Problems in Team (V1) mostly revealed moderate negative correlations with regards to the statement Learning Processes in Teams (V2). The problem of inadequate knowledge and skills of team members (S1) is not showing a statistically significant difference regarding most of the statements in the variable Learning Processes in Teams (V2) except for the following statements: team learning resistance because of additional time (S15') and problems among team members are seen as an obstacle in team learning (S16'). Regarding Learning Processes in Teams (V2), statements which refer to need for implementation new practices and activities (S7') and rapidly developing new skills (S9') are not showing statistically significant correlations with any defined problems in the team.

Table 4. Correlations among statements (S1-S5) in Problems in Team (V1) with regards to statements (S1'-S16') in Learning Processes in Teams (V2)

\begin{tabular}{|c|c|l|l|l|c||}
\hline & \multicolumn{4}{|c|}{ Statements in variable Problems in Team (V1) } \\
\hline $\begin{array}{l}\text { Statements in variable } \\
\text { Learning Processes in } \\
\text { Teams (V2) }\end{array}$ & $\mathrm{S} 1$ & $\mathrm{~S} 2$ & $\mathrm{~S} 3$ & $\mathrm{~S} 4$ & $\mathrm{~S} 5$ \\
\hline S1' & -.039 & $-.264^{*}$ & -.173 & -.208 & $-.249^{*}$ \\
\hline S2' & -.101 & $-.409^{* *}$ & $-.353^{* *}$ & $-.335^{* *}$ & $-.328^{* *}$ \\
\hline S3' & -.076 & $-.254^{*}$ & $-.314^{* *}$ & $-.246^{*}$ & $-.227^{*}$ \\
\hline S4' & -.152 & $-.344^{* *}$ & $-.375^{* *}$ & $-.460^{* *}$ & $-.287^{*}$ \\
\hline S5' & -.090 & $-.330^{* *}$ & $-.391^{* *}$ & $-.268^{*}$ & $-.323^{* *}$ \\
\hline S6' & -.200 & $-.308^{* *}$ & $-.430^{* *}$ & $-.299^{* *}$ & $-.286^{*}$ \\
\hline S7' & .032 & .102 & -.012 & -.072 & .094 \\
\hline S8' $9^{\prime}$ & -.023 & -.196 & $-.291^{* *}$ & .017 & -.072 \\
\hline S10' & .014 & -.113 & -.127 & -.013 & -.052 \\
\hline S11 & -.111 & $-.330^{* *}$ & $-.303^{* *}$ & $-.225^{*}$ & $-.377^{* *}$ \\
\hline S12' & .018 & -.215 & -.123 & $-.318^{* *}$ & -.119 \\
\hline S13' & .021 & $-.222^{*}$ & -.175 & -.119 & -.166 \\
\hline S14' & -.131 & $-.371^{* *}$ & $-.340^{* *}$ & -.207 & $-.238^{*}$ \\
\hline S15' & -.055 & $-.311^{* *}$ & $-.262^{*}$ & $-.242^{*}$ & -.210 \\
\hline S16' & $-.293^{* *}$ & $-.470^{* *}$ & $-.491^{* *}$ & -.116 & $-.383^{* *}$ \\
\hline & $-.326^{* *}$ & $-.417^{* *}$ & $-.379^{* *}$ & -.148 & $-.302^{* *}$ \\
\hline
\end{tabular}

$* * \mathrm{p}<0.01, * \mathrm{p}<0.05$

Regarding the Pearson correlation coefficient presented in Table 5, statements of Problems in Team (V1) mostly revealed moderate negative correlations with regards to statements in Activities in Team Learning Processes (V3). Statements as the extent to which teams use a constructive dialog and discussion (S3') and learning new different methods of work is welcomed (S7') are not showing statistically significant correlations with any of the statements in Problems in Team (V1). 
Table 5. Correlations among statements in Problems in Team (V1) with regards to statements in Activities in Team Learning Processes (V3)

\begin{tabular}{|c|c|c|c|c|c|}
\hline & \multicolumn{5}{|c|}{ Statements in variable Problems in Team (V1) } \\
\hline $\begin{array}{l}\text { Statements in variable } \\
\text { Activities in Team } \\
\text { Learning Processes (V3) }\end{array}$ & $\mathrm{S} 1$ & S2 & $\mathrm{S} 3$ & S4 & S5 \\
\hline $\mathrm{S} 1 \%$ & -.081 & $-.235^{*}$ & $-.287 * *$ & -.110 & $-.243 *$ \\
\hline S2” & -.070 & $-.259 *$ & -.139 & $-.226^{*}$ & $-.258 *$ \\
\hline S3'” & .030 & .041 & .064 & .020 & .066 \\
\hline S4"' & -.173 & $-.336 * *$ & $-.398 * *$ & $-.236 *$ & $-.289 * *$ \\
\hline S5, & -.192 & $-.236^{*}$ & $-.282 *$ & -.204 & $-.263 *$ \\
\hline S6” & -.113 & -.207 & $-.307 * *$ & $-.286^{*}$ & $-.246^{*}$ \\
\hline S7'” & .031 & -.184 & -.087 & -.126 & -.081 \\
\hline S8, & $-.231 *$ & $-.263^{*}$ & $-.439 * *$ & $-.263^{*}$ & $-.365 * *$ \\
\hline
\end{tabular}

$* * \mathrm{p}<0.01, * \mathrm{p}<0.05$

\section{Discussion of Research Findings}

Regarding empirical results presented in Table 2, the key identified problems in teams and consequently in team learning processes and activities are: inadequate knowledge and inexperience of team members (S1), undefined roles of team members (S2), lack of trust among team members (S3), inadequate rewards of team members (S4), and inadequate leadership and team management (S5). These problems are quite close to the theoretical background in knowledge management literature (Gibson \& Vermeulen, 2003; Sarin \& McDermott, 2003; Zellmer-Bruhn \& Gibson, 2006).

Figure 1 shows that appearing of problems in teams has a negative impact on processes and activities of learning - with the appearance and growth of the problems in teams, there is a moderate drop of intensity in team learning processes and activities. These results can be explained with the fact that team members are aware of the importance and significance of learning for the realization of defined team goals. Connected to this, the results in Table 3 show that the problem of inadequate knowledge and inexperience of team members (S1) have no statistically significant correlation, which means that it does not affect the Learning Processes (V2) and Activities in Team Learning Processes (V3). This result is grounded on the fact that knowledge and experience (improvement of existing and acquiring of new knowledge, skills and experience) are the outcome of learning processes and activities (Levitt \& March 1988). On the other hand, all other defined problems in teams (undefined roles of team members (S2), lack of trust among team members (S3), inadequate rewards of team members (S4) and inadequate leadership and team management (S5)) show moderate but statistically significant correlations with 
regards to Learning Processes in Teams (V2) and Activities in Team Learning Processes (V3) (at a significance level of $p<0.05$ and $p<0.01$ ).

Inadequately defined roles of team members (S2) and lack of trust among them (S3) result in confusion, inefficiency, reduced productivity, lack of synergy, empathy, dishonesty and a lack of understanding what is expected from team members during the team learning processes and activities. These problems must be examined carefully because they are barrier to effective functioning of teams which need to be based on sharing of knowledge, positive attitudes, believes and values among team members (Senge, 1990; Edmondson, 1999; Edmondson et al. 2001; Edmondson et al. 2007; Tannenbaum et al. 2012).

The results in Table 4 show that there are moderate negative correlations between Problems in Team (V1) and Learning Processes in Teams (V2). With the appearance and growth of problems of undefined roles of team members, lack of trust among team members, inadequate rewards of team members, inadequate leadership and team management (S2-S5), the processes and activities of learning in teams will be slightly decreased, especially encouragement of team members to freely state their attitudes, solve problems or use their knowledge. Surveyed team members stated that even in the case of the existence of these problems, they will participate in their solving and team learning. That shows that these problems will not have significant negative impact on the participation of team members in identifying problems and finding solutions for them (S10' and S13').

Furthermore, team members stated that appearance of undefined roles of team members (S2), lack of trust (S3), and inadequate leadership and team management (S5), will have moderate impact on their motivation to bring new practices and changes in work. According to the answers of team members, teamwork is stimulative for implementing changes and better work practices (S14') and the existence of undefined roles of team members (S2), lack of trust among team members (S3), and inadequate rewards (S3) will not have a significant effect on their motivation for teamwork. Results show that team members do not see inadequate rewards of team members (S4) as a problem which will have an impact on their interrelations, teamwork and team learning, even if they need to give some additional time and effort (S15' and S16'). Identified problems in the paper did not show correlations regarding the following statements: the need for the implementation of new practices and activities (S7'), and rapidly developing new skills (S9'), which confirms that team members recognize the significance and importance of acquiring new knowledge, skills and their implementation in team processes despite possible problems which may appear.

Team members stated that none of the defined problems will affect the presentation of opposing opinions, ideas and attitudes, and on the learning of new, different methods of doing the job in teams. Furthermore, they stated that conflict dialog will be always used for solving problems in teams, and results presented in 
Table 5 indicate a lack of correlations among Problems in Teams with respect to promptly sharing of opinions and attitudes and the need for an implementation of new practices and activities (S3' 'and S7'). There is a negative correlation between all defined problems (S1-S5) in teams with the statement of team members that they freely state their attitudes, opinions and ideas (S8'). The assumption is that with the appearance and growth of the stated problems, team members will be slightly close in themselves regarding the presentation of their own opinions, ideas and attitudes in order to not confront with other members.

From all the above mentioned, the problem related to inadequate knowledge and inexperience of team members (S1) has not shown a statistically significant impact on learning in Organization X, and furthermore on Learning Processes (V2) (systematic collection and exchange of relevant information, openly sharing of opinions, attitudes, knowledge, and systematic ways of thinking) and Activities in Team Learning Processes (V3) (open recognition of weaknesses and errors, conflict dialog and discussion, team meeting, learning using new and different methods of doing jobs). On the other hand, results show that the other defined problems are in moderate negative correlations with the above stated processes and activities of team learning. That means that with the eventual appearance of the stated problems and their growth, there will be a moderate decrease in team learning in the sense that it will slightly slow down the acquiring of new and improvement of existing knowledge and skills. The processes and activities of learning are not completely stopped with the appearance of problems, because the examined teams are permanent in their nature and their members are aware of the importance of learning processes for achievement of defined teams' and organizational goals.

\section{Conclusion}

Organizational capabilities by which new knowledge, skills and competencies can be fast applied in the working processes and activities have become of tremendous importance for organizational survival and success (Lazarević \& Lukić, 2015). For that reason, establishment of team-based organizational structures and focusing on working teams have become the key building blocks of any modern organization in the world. Team learning has been positioned as a very important factor for the adaptation and responsiveness to changes in environment (Edmondson et al. 2007). But, team learning depends on many factors inside organizations and managers must be aware of those factors in order to create stimulative organizational context for team learning processes and activities.

This paper had the goal to point out to team leaders and managers some of the problems which may appear in teams and cause a threat to team learning processes and activities. The results from research in which participate members from nine teams in one public service organization in Belgrade, Serbia, showed that the eventual appearance of identified problems in teams will not have a significant 
impact on learning processes and activities, which is very encouraging. That indicates that there is awareness and responsibility of team members on the importance of learning and knowledge, despite of the eventual appearance of examined team problems. These results are very encouraging because the fundamental ingredients for learning in teams are team members which constantly seek for information, experimentation, reflection, feedback, active discussion of errors or unexpected results (Edmondson, 1999; Sole \& Edmondson, 2002).

This paper makes its contribution by examining the impact of defined problems, which may appear in a team, on team learning processes and activities and by analysing the relationships among them. The results showed that the problems of undefined roles of team members, a lack of trust among them, inadequate rewards, and inadequate leadership and team management are in moderate negative correlations with team learning processes and activities. That means that with the eventual appearance of the stated problems and their growth, there will be a moderate decrease in team learning in the sense that it will slightly slow down the acquiring of new and improvement of the existing knowledge and skills. The key finding is that the problems will not completely stop or block team learning, but they will slow it down. Therefore, team leaders and managers should be aware of these problems, their impact on team learning and find ways how to overcome them in order to foster team learning. They must have a proactive approach and anticipate team problems even before they appear in order to minimize their negative effects on team learning and the efficiency of team functioning.

Conducted research has some limitations that should be noted. Case study is frequently used method in research of theoretical and empirical procedures in the management and organizational science, but when this method is based on only one organization there are certain limitations in generalization of conclusions from such research (Farquhar, 2012). For this reason, the selection of organization which will be the subject of case study is very important (Yin, 2009). In this research is selected organization for which can be said that is truly representative regarding large and complex organization from the public sector with different working processes and organizational units. The basic structure of selected Organization X is upgraded with numerous working teams, so this fully satisfies the existence of a diversity of work organization and consequently allows adoption of more general assumptions and conclusions with significant scientific value. Having in mind the fact that observed organization is the only one of that type of industry in Serbia, some further researches should encompass more organizations from various industry with regards to the fact that different industries and job nature can be distinguishing factors in examining the team learning processes and activities. 


\section{References}

Argyris, C. \& Schon, D. A. (1978). Organizational Learning: A Theory of Action Perspective. Philippines: Addison-Wesley Publishing Company.

Ashauer, S. A. \& Macan, T. (2013). How Can Leaders Foster Team Learning? Effects of Leader-Assigned Mastery and Performance Goals and Psychological Safety. The Journal of Psychology, 147(6), 541-561.

Babnik, K., Trunk Širca, N. \& Dermol, V. (2014). Individuals learning in work teams: Support to knowledge management initiatives and an important source of organizational learning. Science Direct, 124, 178-185.

Bell, B. S. \& Kozlowski, S. W. J. (2012). Three conceptual themes for future research on teams. Industrial and Organizational Psychology: Perspectives on Science and Practice, 5(1), 45-48.

Bell, B. S., Kozlowski, S. W. J. \& Blawath, S. (2012). Team learning: A theoretical integration and review. In S. W. J. Kozlowski (Ed.), The Oxford handbook of organizational psychology Vol. 2. (pp. 859-909). Oxford, UK: Oxford University Press.

Berber, N. \& Slavić, A. (2016). Obuka ljudskih resursa u Srbiji na bazi CRANET istraživanja. Ekonomske teme, 54(4), 535-548.

Bunderson, J. S. \& Reagans, R. E. (2011). Power, Status, and Learning in Organizations. Organization Studies, 22(5), 1182-1194.

Cohen, J. (1988). Statistical power analysis for the behavioural sciences. New Jersey: Lawrence Erlbaum Associates.

Cunningham, J. B. \& McCrum-Gardner, E. (2007). Power, effect and sample size using GPower: practical issues for researchers and members of research ethics committees. Evidence Based Midwifery, 5(4), 132-136.

Decuyper, S., Dochy, F. \& Van den Bossche, P. (2010). Grasping the dynamic complexity of team learning: An integrative model for effective team learning in organisations. Educational Research Review, 5(2), 111-133.

Edmondson, A. C. (1999). Psychological safety and learning behaviour in work teams. Administrative Science Quarterly, 44(2), 350-383.

Edmondson, A.C., Bohmer, R. \& Pisano, G. (2001). Speeding Up Team Learning. Harvard Business Review, 125-132.

Edmondson, A.C., Winslow, A. B., Bohmer, R. M. \& Pisano, G. P. (2003). Learning How and Learning What: effects of tacit and codified knowledge on performance improvement following technology adoption. Decision Sciences, 34(2), 197-223.

Edmondson, A. C. (2003). Speaking Up in the Operating Room: How Team Leaders Promote Learning in Interdisciplinary Action Teams. Journal of Management Studies, 40(6), 1420-1452.

Edmondson, A. C., Dillon, J.R. \& Roloff, K.S. (2007). Three Perspectives on Team Learning. The Academy of Management Annals, 1(1), 269-314.

Eddy, E. R., Tannenbaum, S. I. \& Mathieu, J. E. (2013). Helping teams to help themselves: comparing two team-led debriefing methods. Personnel Psychology, 66, 975-1008.

Ellis, A. P. J., Hollenbeck, J. R., Ilgen, D. R., Porter, C., West, B. J. \& Moon, H. (2003). Team Learning: Collectively Connecting the Dots. Journal of Applied Psychology, 88(5), 821835.

Farquhar, D. J. (2012). Case Study Research for Business. London: Sage Publications.

Field, A. (2009). Discovering Statistics using SPSS. London: Sage. 
Garvin, D. A. (1993). Building a Learning Organization. Harvard Business Review, 71(4), 7891.

Garvin, D.A., Edmondson, A.C. \& Gino, F. (2008). Is Yours a Learning Organization? Harvard Business Review, 86(3), 109-116.

George, D. \& Mallery, P. (2003). SPSS for Windows step by step: A simple guide and reference. 11.0 update, Boston: Allyn \& Bacon.

Gibson, C. B. \& Vermeulen, F. (2003). A healthy divide: Subgroups as a stimulus for team learning. Administrative Science Quarterly, 48, 202-239.

Goldsmith, M., Morgan, H. \& Ogg, A. J. (2004). Leading Organizational Learning, Harnessing the Power of Knowledge. San Francisco: Jossey-Bass.

Graetz, F. \& Smith, A. (2005). Organizing Forms in Change Management: The Role of Structures, Processes and Boundaries in a Longitudinal Case Analysis. Journal of Change Management, 5(3), 311-328.

Guchait, P. \& Hamilton, K. (2013). The temporal priority of team learning behaviors vs. shared mental models, in service management teams. International Journal of Hospitality Management, 33, 19-28.

Harvey, S., Peterson, R. S. \& Anand N. (2014). The Process of Team Boundary Spanning in Multi-Organizational Contexts. Small Group Research, 45(5), 506-538.

Hedlund, E. \& Österberg, J. (2013). Team Training, Team Learning, Leadership and Psychology Safety: A Study of Team Training and Team Learning Behavior during a Swedish Military Staff Exercise. Sociology Mind, 3(1), 89-98.

Kayes, D. C. \& Burnett, G. (2006). Team Learning in Organizations: A Review and Integration, OLKC Conference at the University of Warwick, Coventry.

Kayes A. \& Kayes D.C. (2011). Team Learning. In: The Learning Advantage. London: Palgrave Macmillan.

Kozlowski, S. \& Ilgen, D. (2006). Enhancing the effectiveness of work groups and teams. Psychological Science in the Public Interest, 7(3), 77-124.

Lazarević, S. \& Krstić, A. (2013). Characteristics of Team Learning in Contemporary Organizations. In: Chova G. L., Martinez L. A. \& Torres C. I. (Eds.): 5th International Conference on Education and New Learning Technologies - EDULEARN13 (pp. 411$420), 1^{\text {st }}-3^{\text {rd }}$ July, Barcelona, Spain.

Lazarević, S. (2014). Team learning in the function of the development of the bureaucratic organization as a learning organization. Themes, 2, 837-853.

Lazarević, S. \& Lukić, J. (2015). Building Smart Organization Throught Learning and Development of Employees. In: Grozdanić R. \& Jovančević D. (Eds.), Creative Education for Employment Growth (pp. 256-268), Monography from The Fourth International Conference EMPLOYMENT, EDUCATION AND ENTREPRENEURSHIP, Belgrade.

Lehmann-Willenbrock, N. (2017). Team Learning: New Insights Through a Temporal Lens. Small Group Research, 48(2), 123-130.

Levitt, B. \& March, J. G. (1988). Organizational learning. Annual Review of Sociology, 14, 319-340.

McShane, S. \& Von Glinow, M. (2009). Organizational Behaviour. Irwin: McGraw Hill.

Miles, R. E., Snow, C. C., Fjeldstad, Ø. D., Miles, G. \& Lettl, C. (2010). Designing Organizations to Meet 21st-Century Opportunities and Challenges. Organizational Dynamics, 39(2), 90-103.

Mohrman, S. A., Cohen, S. G., \& Morhman, A. M., Jr. (1995). Designing team-based organizations: New forms for knowledge work. San Francisco: Jossey-Bass. 
Petković, M. \& Lukić, J. (2014). New organizational forms supported by the information and communication technology: the case of Serbian ICT industry. Facta Universitatis: Economics and Organization, 11(2), 101-115.

Sarin, S., \& McDermott, C. (2003). The effect of team leader characteristics on learning, knowledge application, and performance of cross-functional new product development teams. Decision Sciences, 34, 707-740.

Senge, P. (1990). The Fifth Discipline. The art and practice of the learning organization. London: Random House.

Sole, D. \& Edmondson, A. (2002). Situated knowledge and learning in dispersed teams. British Journal of Management, 13, 17-34.

Tannenbaum, S. I., Mathieu, J. E., Salas, E. \& Cohen, D. (2012). Teams Are Changing: Are Research and Practice Evolving Fast Enough? Industrial and Organizational Psychology, 5, 2-24.

Van der Haar, S., Segers, M. \& Jehn, K. A. (2013). Towards a contextualized model of team learning processes and outcomes. Educational Research Review, 10, 1-12.

Wiedow, A., Konradt, U., Ellwart, T. \& Steenfatt, C. (2013). Direct and Indirect Effects of Team Learning on Team Outcomes: A Multiple Mediator Analysis. Group Dynamics: Theory, Research and Practice, 17(4), 232-251.

Woerkom, M. \& Croon, M. (2009). The relationships between team learning activities and team performance. Personnel Review, 38(5), 560-577.

Yin, R. (2009). Case Study Research: Design and Method. CA: Sage Publications.

Zellmer-Bruhn, M. \& Gibron, C. (2006). Multinational organization context: implications for team learning and performance. Academy of Management Journal, 49(3), 501-518.

\section{PROCESI I AKTIVNOSTI TIMSKOG UČENJA U ORGANIZACIJI: STUDIJA SLUČAJA}

Apstrakt: U današnjim uslovima poslovanja, organizacije se u sve većoj meri oslanjaju na timove i timsko učenje i pozicioniraju ove faktore kao ključne za svoj opstanak i razvoj. Cilj rada je da identifikuje ključne procese i aktivnosti timskog učenja u organizacijama i da istraži kako pojava problema u timu utiče na ove procese i aktivnosti. U istraživanju je učestvovalo 79 članova iz devet timova u organizaciji iz javnog sektora koja posluje u Beogradu, Srbiji. Za obradu i interpretaciju podataka koji su prikupljeni pomoću intervjua i upitnika, primenjene su deskriptivna analiza, linearna regresija i Pirsonov koeficijent korelacije. Rezultati istraživanja su pokazali da nejasno definisane uloge članova tima, nedostatak poverenja između njih, neadekvatan sistem nagrađivanja, liderstva i upravljanja imaju negativan uticaj na procese i aktivnosti timskog učenja. Dobijeni rezultati istraživanja su od značaja za menadžere i lidere koji imaju za cilj da uspostave pogodan organizacioni kontekst za timsko učenje, ali i da predvide i prevaziđu sve probleme koji se mogu pojaviti u timu i koji mogu uticati na procese i aktivnosti timskog učenja.

Ključne reči: timovi, timsko učenje, problemi u timu, procesi, aktivnosti 


\section{Authors' biographies}

Snežana Lazarević is an Assistant Professor in College of Sports and Health in Belgrade. She is the author or co-author of several scientific research papers published in relevant national journals of international importance. She has many years of leadership and management experience in institutions of higher education. Her main research areas are: Organizational Behaviour, Human Resource Management, Teams and Teamwork and Management in Sport.

Jelena Lukić is an Assistant Professor at Modern Business School in Belgrade. She is the author or co-author of several scientific research papers published in relevant national journals of international importance in the field of information and communication technologies and organizational design. Her main research areas are: Organizational Design, Soft Skills, Information and Communication Technologies and Big Data. 